\title{
Hydrochemical Characterisation of Groundwater Quality: Merdja Plain (Tebessa Town, Algeria)
}

\author{
Baazi Houria ${ }^{a^{*}}$, Kalla Mahdi ${ }^{\text {a }}$, Tebbi Fatima Zohra ${ }^{\text {a }}$ \\ ${ }^{a}$ Natural Hazards and Territory Planning Laboratory (LRNAT), Earth Sciences and Universe Institute, Mustapha Benboulaid, Batna 2 \\ University, Algeria.
}

Received 09 October 2019; Accepted 28 December 2019

\begin{abstract}
The objective of this work is to evaluate the physico-chemical quality of the groundwater of the Merdja plain and to determine the sources of mineralization. This quality is influenced by several environmental and anthropogenic factors such as geological context, climate, precipitation and interaction between groundwater and aquifers and human activities. A Principal Component Analysis (PCA) on samples taken from several wells spread over the entire Tebessa plain (Merdja) allowed us to detect two axes that explain $73.4 \%$ of the information. The first axis describes the variables related to mineralisation and the second one describes those related to agricultural activity. Multidimensional Positioning (MDS) confirmed the interaction of physico-chemical parameters between them and their influence on groundwater quality by highlighting three groups of wells according to their physico-chemical characteristics, particularly those containing high concentrations of nitrates. This contamination is mainly the result of spreading the fertilisers and wastes that are dumped into the plain without treatment. Salinization is the result of long-term interactions between groundwater and geological formations.
\end{abstract}

Keywords: El Medja Plain; Groundwater; Hydrochemical; Geological Formations; PCA; MDS.

\section{Introduction}

Tébessa region is located near the Algerian-Tunisian borders, in the eastern part of the Saharan Atlas, between the Tellian Atlas and the Saharian platform. According to Vila (2002) and Kowalski et al. (2002) this is a very neotectonized domain, which extends into extreme western Tunisia, belongs to the area of diapirs and grabens. Due to its recharge modalities, the water from the Tébessa aquifer presents a high risk of increasing its mineralization $[1,2]$. Over the past few decades, the alluvial groundwater of Tébessa has undergone a rapid deterioration in the chemical quality of these waters [3-5]. Indeed, this phenomenon is simultaneously attributed to the geological context and the semi-arid climate. It is crossed with an over exploitation of the modest resource to meet the needs of drinking water supply and crop irrigation. However, the problem of groundwater pollution has been addressed in several studies focusing on the vulnerability of the aquifer to contamination by salts from saline soils and Triassic out crops, or to pollution by nitrates. This paper highlights only the most recent and complete studies.

In order to identify the processes of mineralization, its origin and evolution in time and space, Gouaidia et al. (2012) monitored water chemistry during two hydrological cycles covering the periods of low and high water. Results showed that mineralization processes are linked to the lithology of the aquifer presented, mainly by evaporites and carbonates. Water-rock interaction phenomena are at the origin of the spatial variation of groundwater geochemistry. On the other

* Corresponding author: hou.baazi@gmail.com

http://dx.doi.org/10.28991/cej-2020-03091473

(C) 2019 by the authors. Licensee C.E.J, Tehran, Iran. This article is an open access article distributed under the terms and conditions of the Creative Commons Attribution (CC-BY) license (http://creativecommons.org/licenses/by/4.0/). 
hand, climatic conditions are responsible for variations in concentrations due to precipitation (dissolution) and temperature (evaporation) [6].

Rouabhia et al. (2009) have used data obtained from the same area through a sampling period (December 2008) and indicates that nitrate affects groundwater due to the use of nitrogen $(\mathrm{N})$ fertilizers in agriculture and also showed that chemical composition of the water is not only influenced by agricultural practices, but also by interaction with the alluvial sediments [4].

Following up evolution trend of hydrochemical parameters of the "Merdja" aquifer Zereg et al. 2018 confirmed that point sources of nitrate and salinity pollution are particularly downstream in the areas surrounding Tebessa [7].

Multivariate statistical tools in the treatment of analytical and environmental data are very important [8,9]. Especially Principal Component Analysis (PCA) which is widely used in water quality analysis [10]. The latter assumes a linear relationship between the data and the underlying latent variables represented by the principal components. Because of this we propose to anticipate any non-linear relationship between the data by using Multidimensional Positioning Scaling (MDS), this method assumes no relationship between variables and attempts to optimise the fit between the dissimilarity between observations and their euclidean distance [11].

The purpose of this study is to investigate the hydrogeochemical characteristics of groundwater in the Merdja plain of Tebessa town. Using two multivariate analysis the classical Principal Component Analysis (PCA) and the Multidimensional Positioning Scaling (MDS) method to extract the most weighting variables and also to identify the main causes of the degradation of the quality of these waters.

\section{Study Area}

The study area totals $288 \mathrm{~km}^{2}$ (Figure 1), and extends between latitudes $35^{\circ} 2^{\prime}$ and $35^{\circ} 6^{\prime}$ North and longitudes $7^{\circ} 87^{\prime}$ and $8^{\circ} 43^{\prime}$ East, upstream of the Mellegue catchment area. The Tébessa plain, with an average altitude of $850 \mathrm{~m}$, is drained by the Chabro and El Kébir Wadi, while many narrow and winding ravines, shaped by temporary torrents, drain their waters to the main wadi.

The present zone with a semi-arid climate receives average interannual rainfall not exceeding $350 \mathrm{~mm} / \mathrm{year}$, with very significant temperature variations in this region, with the minimum extreme temperature reaching $-5^{\circ} \mathrm{C}$, while the maximum temperature exceeds $40^{\circ} \mathrm{C}$. The rainy season generally extends from winter to spring. The period of low water begins in May and continues until October when there is a high evaporation capacity, unlike infiltration, which represents only $1 \%$ of precipitation.

As a result, the supply of water to the groundwater table from rainfall is very low. Due to these climatic conditions, the vegetation is quite poor and sparse. The population is mainly concentrated around the city of Tébessa, whose main activity is agriculture and trade. The industry is relatively under-represented and consists of a few state-owned companies.

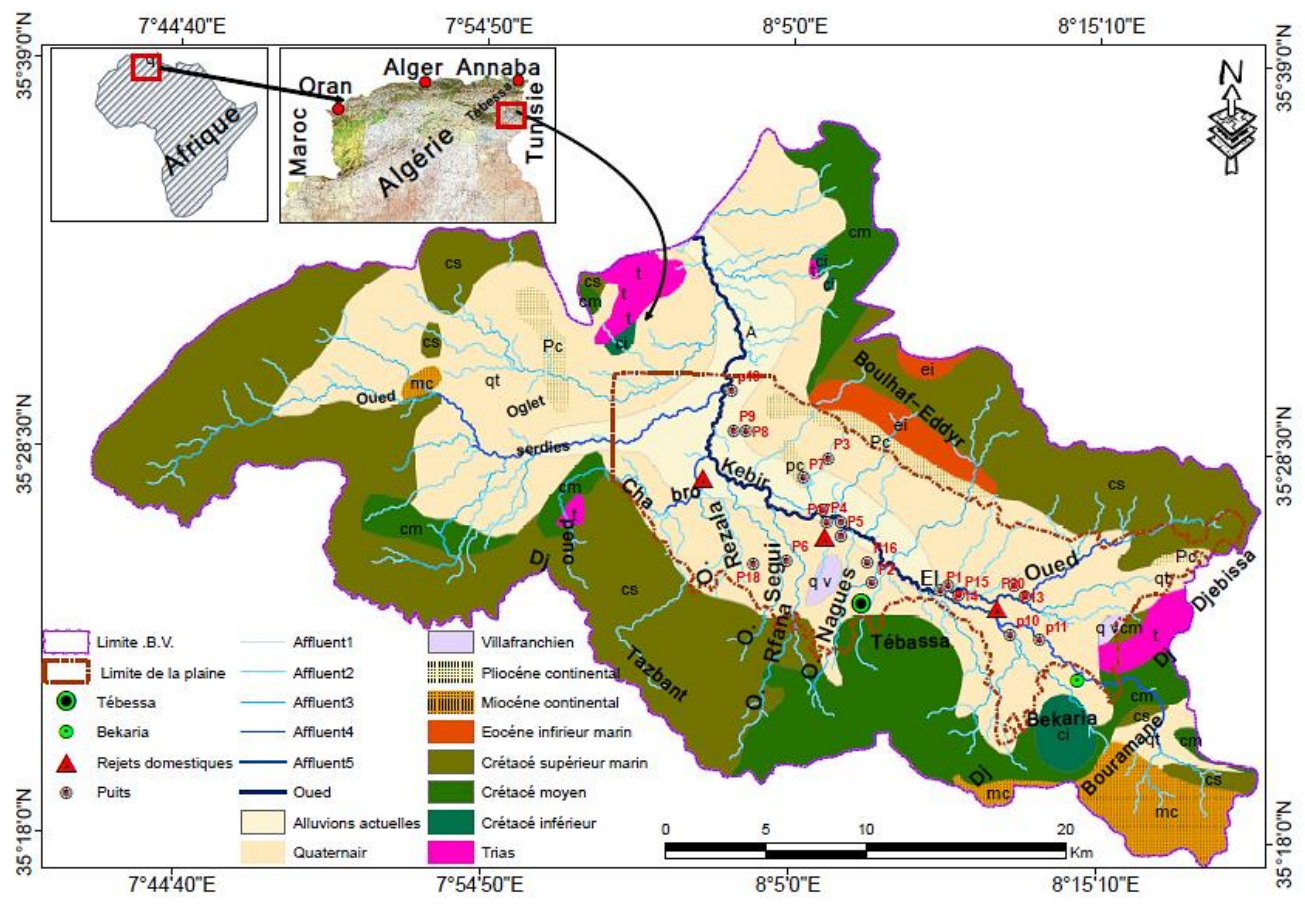

Figure 1. Study Area 
Along the border of the Maghreb mountain range, the Eastern Saharan Atlas is characterized by subsidence, diapirism, folding, faults and collapse ditches $[1,2]$.

The Triassic consists of multicoloured gypsum marls, dolomites, dolomitic limestones, sandstones and fragments of green rocks, typical of the Triassic in Algeria. It constitutes Djebel Djebissa (housing an irondeposit) at the far east of the basin, and outcrops in the northwestern part of the basin (Boulhaf-le-Dir). The lower Cretaceous, with a thickness of about $1000 \mathrm{~m}$, is composed of platform carbonates topped with marl, marl and limestone, as well as clay and clay limestone, while the upper Cretaceous, about 2000 m thick, the Campanian and the Maestrichtian are composed mainly of chalky limestone.

The Eocene is composed of $200 \mathrm{~m}$ thick flint limestone. The Upper Mioceneis continental and out crops south of the Roman Jebel Bou. The Plioceneis of marine and continental type. It is composed of conglomerates, marl and sandstone, Quaternary deposits consist of soils with heterogeneous lithology, such as silts, limestone crusts and pebbles.

\section{Materials and Methods}

\subsection{Sampling and Analysis}

Water samples (Table 1) were extracted from the wells collecting the groundwater. Samples were collected at the end of the rainy season (May).

The physico-chemical parameters, $\mathrm{pH}$, temperature and electrical conductivity, were measured in situ and the analysis of major ions was carried out by flameatomic absorption for cations and by colorimetry for anions [12] at the laboratory of the National Hydraulic Resources Agency (ANRH) in Constantine.

Table 1. Descriptive Statistics of chemical elements

\begin{tabular}{cccccccccc}
\hline Variable & $\mathbf{C E}$ & $\mathbf{C a} 2$. & $\mathbf{M g 2}$. & Na. & $\mathrm{K}$ & $\mathbf{C l}$ & $\mathbf{S 0 4}^{2-}$ & $\mathrm{HCO}_{3}$ & $\mathbf{N O}_{3}$ \\
\hline Min. & 1351 & 96 & 58 & 86 & 1 & 110 & 204 & 165 & 1 \\
1st & 1736 & 132 & 66.25 & 106 & 1 & 172.5 & 351 & 293 & 7 \\
Median & 1981 & 158 & 84 & 122 & 2.5 & 220 & 392 & 369 & 30.5 \\
Mean & 1900 & 159.6 & 85.5 & 141.2 & 4.85 & 216.9 & 420.2 & 352.4 & 41.5 \\
3rd & 2112 & 194.5 & 101.5 & 178 & 8 & 251 & 452.5 & 409 & 62.75 \\
Max. & 2402 & 226 & 124 & 225 & 14 & 375 & 900 & 451 & 120 \\
\hline
\end{tabular}

\subsection{Principal Component Analysis}

The objective of PCA analysis is to move from data space to factor space in order to reduce the number of variables and make the information less redundant. This is equivalent to replacing the variables $x 1, \ldots x p$ which are initially correlated by new variables called main components $c 1, \ldots c p$ uncorrelated. These variables are linear combinations of $x j$, they are of maximum variance and obtained by inertial maximization.

Principal Component Analysis is widely used for water quality characterization [8, 13-15]. Chaïb and Samraoui (2011) applied this method to characterize the waters of the East Kebir Wadi (Algeria), which allowed them to identify the main causes of degradation and to assess the physico-chemical quality of the waters of this and its main tributaries [14].

Mishra (2010), during a monitoring of the Ganges River in Varanasi, used the PCA to extract the parameters that are most important in assessing the quality of these waters and concluded that only four main factors were identified as responsible for the structure of the data explaining $90 \%$ of the total variance of the data set [8]. Mahapatra et al. (2012) applied Principal Component Analysis to classify water samples into four different categories, this classification will be useful for planners to take improvement measures in advance, to prevent groundwater contamination [16].

\subsection{Multidimensional Scaling (MDS)}

Multi-dimensional Scaling [17] or proximity analysisis is a special case of multivariate analysis with which one can reconstruct an image in a Euclidean space from one or more tables of distances or dissimilarities between objects (individuals). It aims to best represent objects in a visualizable space, so that the distances between objects in this space are as close as possible to the initial dissimilarities [18]. The optimal space being obtained by minimizing the Stress (Standardized Residual Sum of Squares) criterion [17]. Let $d_{i j}, \delta_{i j}$ be dissimilarities and real distances, respectively. 


$$
\text { Stress }=\left(\frac{\sum_{i j} \sum_{i j}\left(\delta_{i j}-d i j\right)^{2}}{\sum_{i j} \sum_{i j}(d i j)^{2}}\right)^{1 / 2}
$$

MDS is based on an iterative approach illustrated by the:

1. Initialization (random or not) of the coordinates of the objects in the plane,

2. Calculation of distances between objects in the plane,

3. Calculation of the disparities between the distances in the plane and the distances in the original space,

4. Calculation of a cost function based on these disparities,

5. Update the coordinates of the objects in the plane and return to step 2.

There are two types of MDS: (i) the metric MDS and (ii) the non-metric NMDS the latter has the advantage of having no assumption made about the underlying transformation function [18]. This characteristic allows the technique to be applied to several fields of study [19]. The Non-Metric Multidimensional Scaling (NMMDS) method is based on minimizing the criterion:

Stress $=\left(\frac{\sum_{i j} \sum_{i j}\left(f\left(\delta_{i j}\right)-d i j\right)^{2}}{\sum_{i j} \sum_{i j}(d i j)^{2}}\right)^{1 / 2}$

Where, $f$ is an increasing monotonous function (to be determined by the resolution algorithm) of dissimilarities [20]. Stress values close to zero indicate that the results of the MDS analysis are reasonable and reliable. Several authors have used MDS to characterize water quality [21, 13].

Wu et al. (2011), using MDS analysis, identified the spatial and temporal variability of hydrochemical water quality in a subtropical coastal system, Daya Bay, China [13]. Group I was identified as being mainly related to anthropogenic activities, both in terms of Group II and in terms of trade in sea water from the South China Sea. Vargas-González et al. [22], based on a NMDS analysis of water samples from the Gulf of California, showed the existence of different hydrological conditions each season. The marked differences between summer and winter are attributed to water temperature and phytoplankton biomass on the one hand and summer conditions in La Salada Cove on the other.

\section{Results and Discussion}

PCA analysis was performed using $\mathrm{R}^{\odot}$ software with the adopted Factominer, Factoextra and Performance Analytics packages. The link between all the variables taken in pairs and the correlation coefficients between these different variables is given by the correlation matrix (Figure 2). Indeed, perfect correlations were first recorded between Calcium and Electrical Conductivity $(\mathrm{r}=0.84)$. This indicates that most of the Electrical Conductivity of the water in the study area comes from Calcium. In addition to being correlated with CE, Calcium and Magnesium are both strongly correlated with each other $(\mathrm{r}=0.90)$, which confirms their origin which is the dissolution of carbonate formations, and gypsum formations (evaporite).

Also, a high correlation between Chlorine and Magnesium ( $\mathrm{r}=0.69)$ was recorded. In addition, sulphates are well correlated with sodium ( $\mathrm{r}=0.6)$ and a strong correlation with electrical conductivity, and this can be explained by the dissolution of evaporative formations.

However, a high correlation between nitrate and potassium values $(r=0.69)$ was observed, which proves their origin. The dissolution of chemical fertilizers due to fertilizer abuse and a relatively high correlation between $\mathrm{Cl}$ and $\mathrm{Ca}(0.68)$ also was observed. This is due to the mechanisms for acquiring the salt load of water disturbed by several phenomena, such as the basic exchanges that characterize highly mineralized water, the leaching of evaporation levels and the dissolution of gypsum and halite, which can increase the calcium and chloride ion content respectively.

In addition, a strong relationship between $\mathrm{Cl}$ and $\mathrm{K}(0.74)$ suggests that some of the chlorides come from the dissolution of $\mathrm{KCl}$ but that the majority of these cations could come from the dissolution of other minerals.

The insignificant relationship between sulphates and calcium and magnesium is probably due to the fact that calcium and magnesium ions are involved in dissolution/precipitation phenomena in basic exchanges on clay minerals, whereas TDS is related to the main elements, $\mathrm{Ca}, \mathrm{Mg}, \mathrm{CE}$ and $\mathrm{SO} 4$ with a correlation coefficient that varies between 0.67 and 0.97 . 


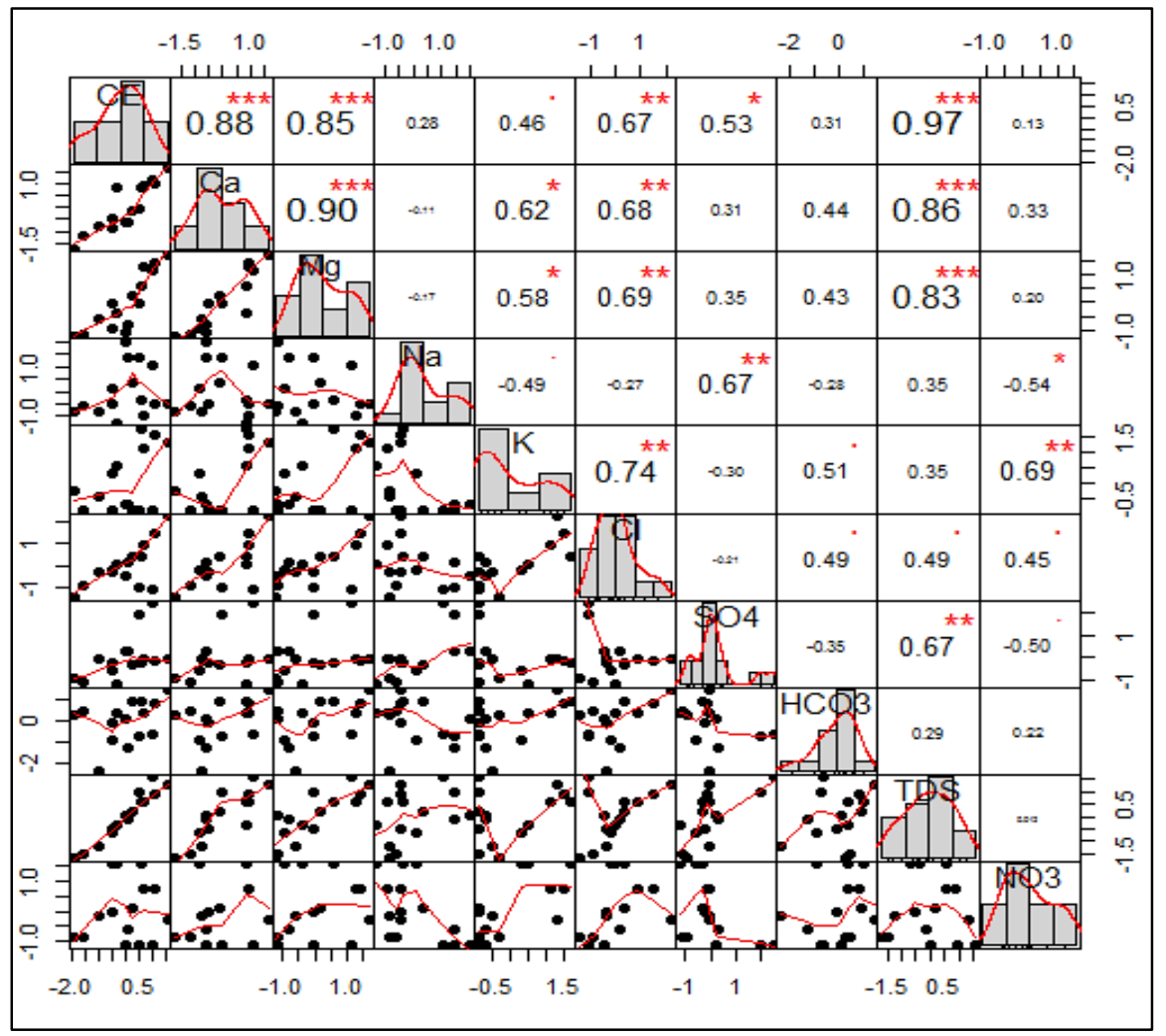

Figure 2. Correlation matrix

To confirm the interpretations made above and to make it easier to visualize the influence of the physico-chemical parameters between them and on the quality of the water of the Tébessa plain. The scree plot has identified two axes that carry $80.3 \%$ of the information contained in these variables (Figure 3), while projections made on both axes show that axis 1 summarizes $50.1 \%$ of the information and describes the variables related to mineralization $(\mathrm{Cl}, \mathrm{Mg}, \mathrm{SO} 4$, electrical conductivity, $\mathrm{Ca}, \mathrm{NO} 3$ and K). It can be considered as a gradient of mineralization related to the intensity of pollution provided by urban spills and industrial waste water companies [23].

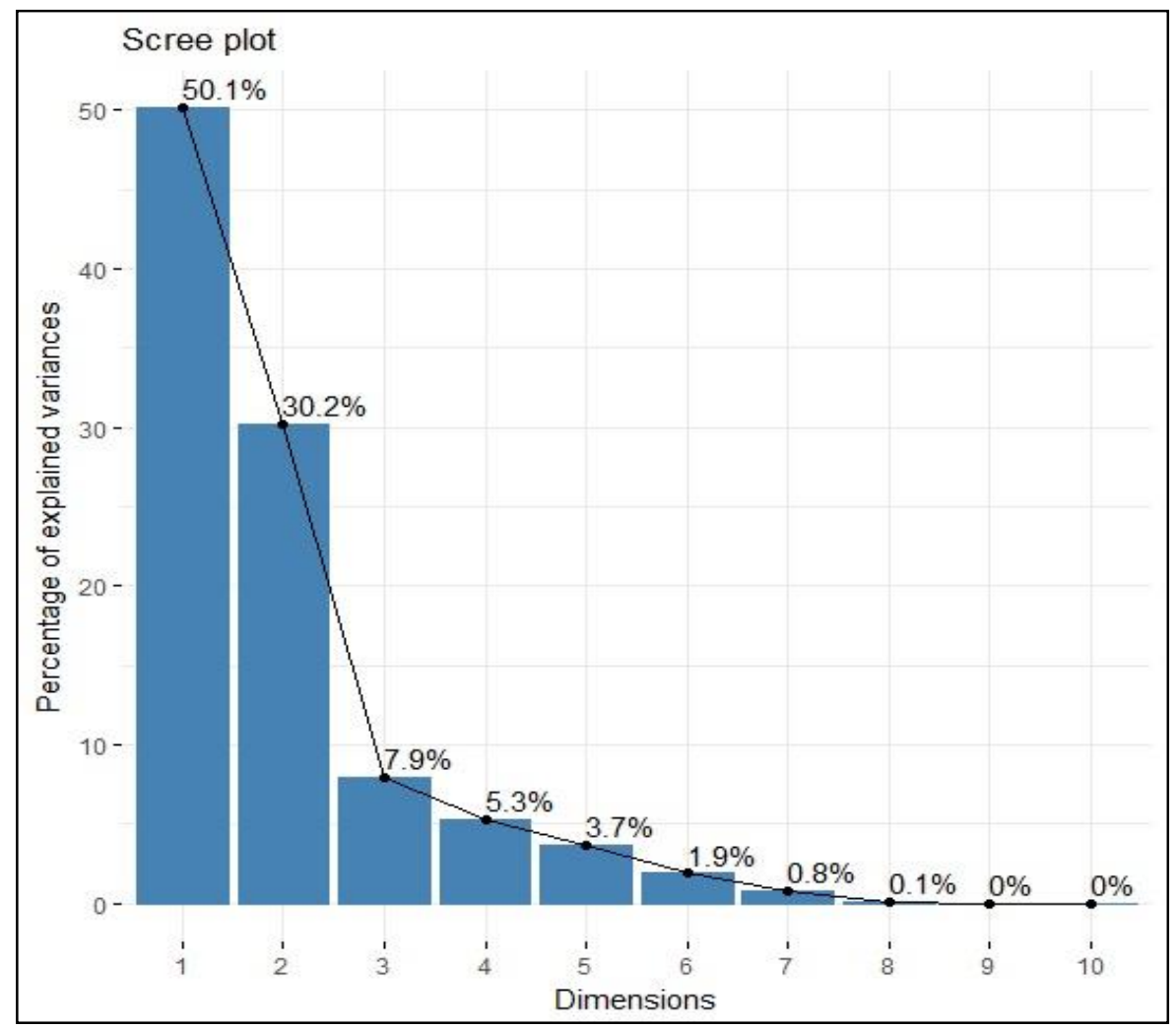

Figure 3. Scree plot 
Projections made on the first two axes (Figure 4) show that: axis 1 summarizes $50.1 \%$ of the information and describes the variables related to mineralization: $(\mathrm{Cl}, \mathrm{Ca}, \mathrm{Mg}$ and $\mathrm{CE}$ ). Axis $\mathrm{F} 2$ expresses $30.2 \%$ of the initial information, it is positively correlated by nitrates and potassium, it is linked to agricultural activity which is due to the use of fertilizers [4].

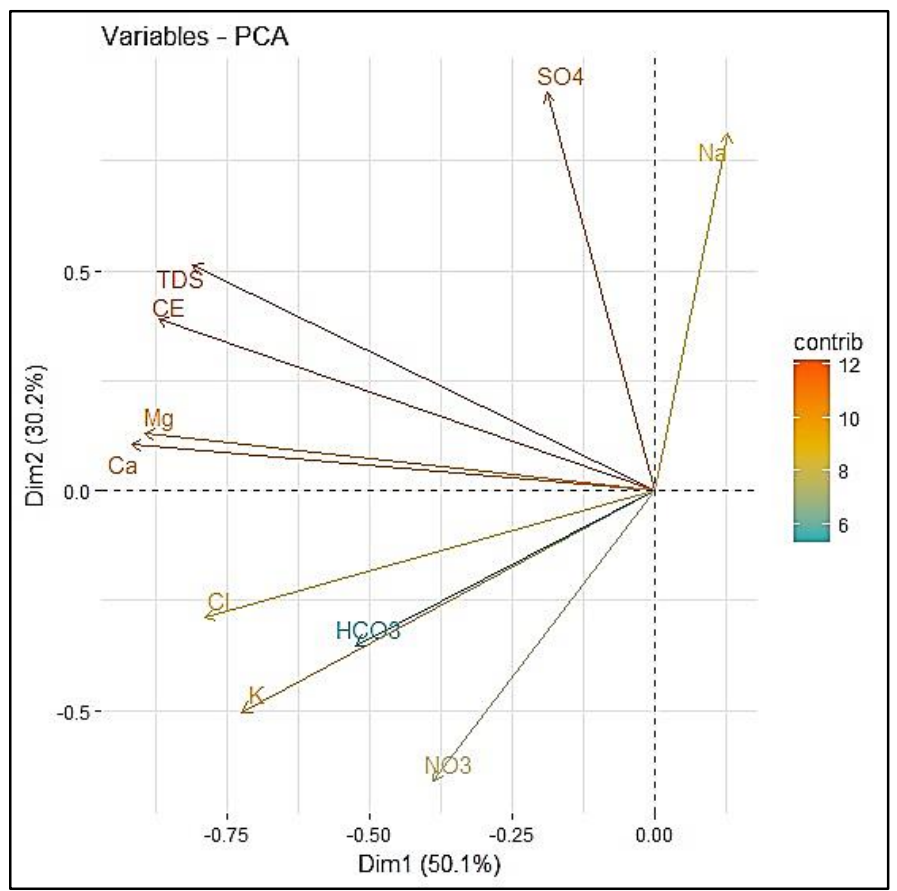

Figure 4. Projection on the first 2 main axes

The MDS analysis carried out with R confirms the results found by the PCA, which has divided the site into three groups of wells, which differ in their physico-chemical quality (Figure 5). The first Group G1 includes wells containing high concentrations of $\mathrm{No} 3, \mathrm{Ca}, \mathrm{K}, \mathrm{Cl}, \mathrm{Cl}, \mathrm{Mg}$, So4 and electrical conductivity which is closely related to pollution caused by urban and industrial wastewater discharges $[4,7]$.

Concerning the second Group G2, on one hand, it maintains the relationship between the two elements NO3 and K caused by fertilizers used in agriculture $[4,7]$ and on the other hand, the relationship between $\mathrm{Ca}, \mathrm{Mg}$ and SO 4 due to the geological formations of the region with average values [6,7]. Group3 reflects the strong relationship between TDS, $\mathrm{Mg}$, SO4 and $\mathrm{Ca}$ which reflects the salinity of this groundwater resulting from the long-term interaction between it and the different geological formations [7].

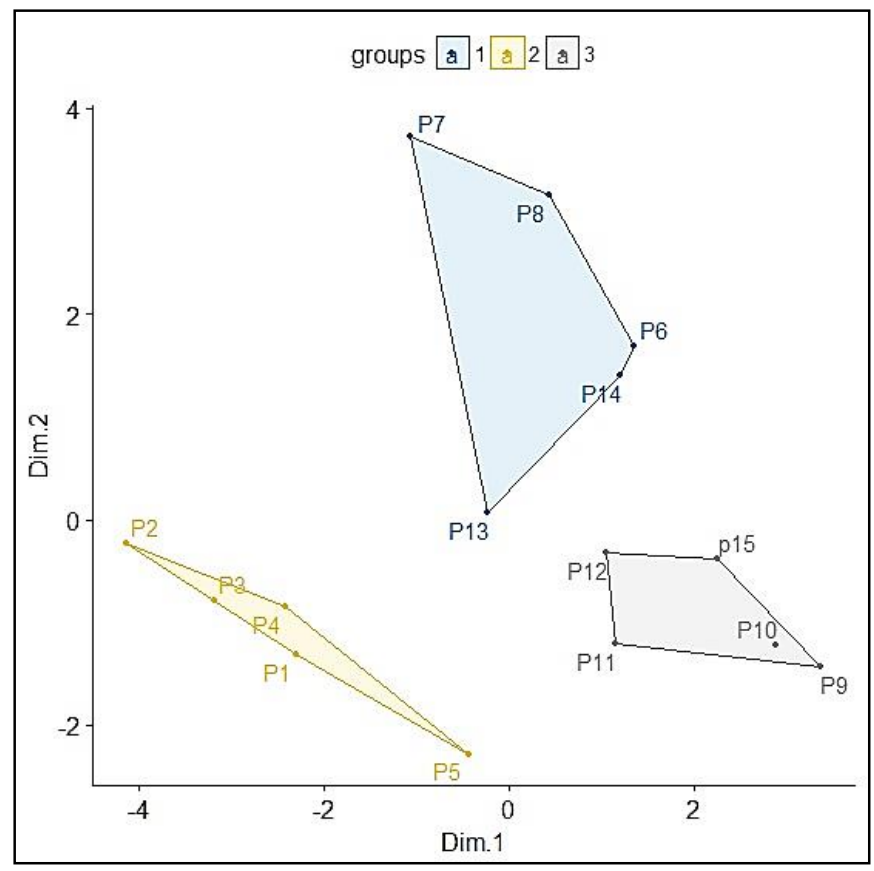

Figure 5. MDS Clustering 


\section{Conclusion}

The study carried out in the Tebessa plain highlighted the main characteristics of groundwater. The groundwater has high concentrations of nitrates, which can reach $120 \mathrm{mg} / \mathrm{l}$. Contamination results mainly from the spreading of fertilizers and waste that is discharged into the plain without treatment. However, a strong correlation between nitrates and potassium proves that they are of anthropogenic origin.

The strong relationship between TDS and $\mathrm{Ca}, \mathrm{Mg}, \mathrm{CE}$ and $\mathrm{SO} 4$ indicates that these elements contribute to groundwater salinity and that groundwater follows a similar pattern. Groundwater salinization is a result of long-term interactions effects between groundwater and geological formations. On the other hand, the insignificant relationship between sulphates and calcium and magnesium is probably due to the fact that calcium and magnesium ions are involved in dissolution/precipitation phenomena in the basic exchanges on clay minerals.

\section{Conflicts of Interest}

The authors declare no conflict of interest.

\section{References}

[1] VILA, J-M. "Les avantages d'une approche multi-sources (biostratigraphie, sédimentologie, forages, profils sismiques et gravimétrie) pour l'étude de l'halocinèse crétacée (glaciers de sel, tectonique en radeaux et dômes de sel) et de l'halotectonique tertiaire (plissement des glaciers de sel, genèse des dômes de sel-plis), des confins algéro-tunisiens." Bulletin du Service géologique de l'Algérie 12, no. 2 (2001): 129-167.

[2] Kowalski, W. M., M. Hamimed, and A. Pharisat. "Les étapes d'effondrement des grabens dans les confins algéro-tunisiens." Bulletin du Service géologique de l'Algérie 13, no. 2 (2002): 131-152.

[3] Fehdi, Chemseddine, Abdelkader Rouabhia, Abdelbasset Mechai, Manel Debabza, Khalida Abla, and Kostas Voudouris. "Hydrochemical and Microbiological Quality of Groundwater in the Merdja Area, Tébessa, North-East of Algeria." Applied Water Science 6, no. 1 (June 10, 2014): 47-55. doi:10.1007/s13201-014-0209-3.

[4] Rouabhia, Abdelkader, Fethi Baali, and Chemseddinne Fehdi. "Impact of Agricultural Activity and Lithology on Groundwater Quality in the Merdja Area, Tebessa, Algeria.” Arabian Journal of Geosciences 3, no. 3 (August 27, 2009): $307-318$. doi:10.1007/s12517-009-0087-4.

[5] Legrioui, Radhia, Fethi Baali, Ilhem Abdeslam, Amor Hamad, Philippe Audra, Didier Cailhol, and Stéphane Jaillet. "Hydrochemical and Isotopic Characterization of Karst Aquifer in the Region of Tebessa, Northeast Algeria." Eurokarst 2018, Besançon (April 10, 2019): 223-231. doi:10.1007/978-3-030-14015-1_25.

[6] Gouaidia, Layachi, Omar Guefaifia, Abderahmane Boudoukha, Mohamed LaidHemila, and Claude Martin. "Évaluation de La Salinité Des Eaux Souterraines Utilisées En Irrigation et Risques de Dégradation Des Sols: Exemple de La Plaine de Meskiana (Nord-Est Algérien).” Physio-Géo no. Volume 6 (February 26, 2012): 141-160. doi:10.4000/physio-geo.2632.

[7] Zereg S, Boudoukha A, Benaabidate L (2018) Impacts of natural conditions and a Zereg, Salah, Abderrahmane Boudoukha, and Lahcen Benaabidate. "Impacts of Natural Conditions and Anthropogenic Activities on Groundwater Quality in Tebessa Plain, Algeria.” Sustainable Environment Research 28, no. 6 (November 2018): 340-349. doi:10.1016/j.serj.2018.05.003.

[8] Mishra, A. “Assessment of Water Quality Using Principal Component Analysis: A Case Study of the River Ganges.” Journal of Water Chemistry and Technology 32, no. 4 (August 2010): 227-234. doi:10.3103/s1063455x10040077.

[9] González, Soledad Oliva, Cesar A. Almeida, Sylvia Quintar, Miguel A. Mallea, and Patricia S. González. "Application of Multivariate Statistical Techniques to Evaluate Organic Pollution on a River in Argentina." Ambiente e Agua - An Interdisciplinary Journal of Applied Science 6, no. 3 (December 31, 2011): 27-42. doi:10.4136/ambi-agua.696.

[10] Johnson, Glenn W., Robert Ehrlich, William Full, and Scott Ramos. "Principal Components Analysis and Receptor Models in Environmental Forensics." Introduction to Environmental Forensics (2007): 207-272. doi:10.1016/b978-012369522-2/500087.

[11] Zand, Martin, Jiong Wang, and Shannon Hilchey. "Graphical Representation of Proximity Measures for Multidimensional Data.” The Mathematica Journal 17 (2015). doi:10.3888/tmj.17-7.

[12] Rodier, Jean, Ch Geoffray, and L. Rodi. L'analyse de l'eau: eaux naturelles, eaux résiduaires, eau de mer: chimie, physicochimie, bactériologie, biologie. Dunod, 1975.

[13] Wu, Mei-Lin, You-Shao Wang, Jun-De Dong, Cui-Ci Sun, Yu-Tu Wang, Fu-Lin Sun, and Hao Cheng. "Investigation of Spatial and Temporal Trends in Water Quality in Daya Bay, South China Sea.” International Journal of Environmental Research and Public Health 8, no. 6 (June 22, 2011): 2352-2365. doi:10.3390/ijerph8062352. 
[14] Chaïb, Nadjla, and Boudjéma Samraoui. "Évaluation de la qualité physico-chimique des eaux de l'oued Kébir-Est et de ses principaux affluents (Nord-Est algérien)." Science et changements planétaires/Sécheresse 22, no. 3 (2011): 171-177. doi:10.1684/sec.2011.0309.

[15] Kassahun, Yared, and Tesfu Kebedee. "Application of Principal Component Analysis in Surface Water Quality Monitoring." Principal Component Analysis - Engineering Applications (March 7, 2012). doi:10.5772/38049.

[16] Mahapatra, S. S., Mrutyunjaya Sahu, R. K. Patel, and Biranchi Narayan Panda. "Prediction of Water Quality Using Principal Component Analysis.” Water Quality, Exposure and Health 4, no. 2 (May 4, 2012): 93-104. doi:10.1007/s12403-012-0068-9.

[17] Kruskal, J. B. "Multidimensional Scaling by Optimizing Goodness of Fit to a Nonmetric Hypothesis." Psychometrika 29, no. 1 (March 1964): 1-27. doi:10.1007/bf02289565.

[18] Manolova, Agata. "Catégorisation par mesures de dissimilitude et caractérisation d'images en multi échelle." PhD diss., 2011.

[19] Zhang, Jin. Visualization for information retrieval. Vol. 23. Springer Science \& Business Media, 2007.

[20] Faye, P., P. Courcoux, M. Qannari, and A. Giboreau. "Méthodes de traitement statistique des données issues d'une épreuve de tri libre." Revue Modulad 43 (2011): 1-24.

[21] Yerel, Suheyla, and Huseyin Ankara. "Assessment of Water Quality Parameters by Using the Multidimensional Scaling Analysis.” E-Journal of Chemistry 7, no. 4 (2010): 1274-1277. doi:10.1155/2010/868724.

[22] Vargas-González, Héctor Hugo, José Alfredo Arreola-Lizárraga, Renato Arturo Mendoza-Salgado, Lía Celina MéndezRodríguez, Carlos Hernando Lechuga-Deveze, Gustavo Padilla-Arredondo, and Miguel Cordoba-Matson. "Effects of Sewage Discharge on Trophic State and Water Quality in a Coastal Ecosystem of the Gulf of California." The Scientific World Journal 2014 (2014): 1-7. doi:10.1155/2014/618054.

[23] Bouzid-Lagha, Souaad, and Belkheir Djelita. "Study of eutrophication in the Hamman Boughrara Reservoir (Wilaya de Tlemcen, Algeria)." Hydrological Sciences Journal 57, no. 1 (2012): 186-201. doi:10.1080/02626667.2011.634417. 